\title{
Intussusception in Adults: Report of Four Cases and Review of the Literature
}

\author{
Jan W. Duijffa Boke L.S. Borger van der Burga \\ Nico J.M. Aarts ${ }^{b}$ Sabine A.J. Loyson ${ }^{c}$ Onno R. Guicherit ${ }^{a}$ \\ Departments of aSurgery, ${ }^{\mathrm{b}}$ Radiology, and 'Pathology, Bronovo Hospital, \\ The Hague, The Netherlands
}

\section{Key Words}

Intussusception, small bowel · Intussusception, large bowel · Intussusception, resection ·

Hemicolectomy $\cdot$ Clear cell sarcoma

\begin{abstract}
Intussusception in adults is a rare clinical entity. The individual surgeon will not often encounter this condition. A lead-point for adult intussusception exists in $90 \%$ of cases and is frequently malignant. We present four cases and discuss treatment and diagnostic modalities. A comprehensive review of the literature is given. All cases were treated by resection according to oncologic principles without previous reduction. Histological examination showed non-Hodgkin lymphoma, lipoma, clear cell sarcoma and adenocarcinoma as the lead-points.
\end{abstract}

\section{Introduction}

Intussusception is defined as prolapse of a proximal bowel segment into a distal segment. It is rare in adults but relatively common in children. Childhood intussusceptions are idiopathic in $90 \%$ of cases and can safely be reduced. In adults, $1-5 \%$ of bowel obstructions are caused by intussusception. A causal lesion, the lead-point, is identified in $90 \%$ [1-6]. Intraluminal masses cause abnormal peristaltic movements and therefore can be the lead-point for intussusception. Distinction must be made between small and large bowel intussusception. Large bowel intussusception is most frequently caused by malignant lesions (63-80\%) [1-6]. The small bowel accounts for only $3 \%$ of all gastro-intestinal malignancies [7]. Small bowel intussusception is less likely to be caused by a malignancy (14-47\%). Benign causes include lipoma, leiomyoma, haemangioma, adhesions, Meckel's diverticulum, celiac disease, Henoch-Schönlein purpura, lymphadenitis, anastomosis, trauma or idiopathic [1-6]. Intussusceptions usually present with symptoms of bowel obstruction (vomiting, nausea, abdominal distension, pain). 
Blood loss or a palpable mass are present in a minority of cases. Symptoms can be acute, intermittent or chronic [1-6].

\section{Case Reports}

Patient A, a 86-year-old woman, was seen because of loss of appetite, weight loss of $10 \mathrm{~kg}$, fatigue, and pain in the right lower abdomen since three months. She had no relevant medical history and did not use any medication. Physical examination revealed abundant peristalsis. A tender mass was palpated in the right lower abdomen. Laboratory findings only showed normocytic anemia. Intussusception of small bowel in the ascending colon was revealed by ultrasonography. The classical 'target sign' was seen; intestinal vascularization seemed intact with patent Doppler flow signals (fig. 1). On laparotomy, ileocolic intussusception was found. The intussuscepted small bowel was not reduced. Right hemicolectomy according to oncologic principles followed. Postoperative recovery was uncomplicated and the patient was discharged on the ninth postoperative day. Pathology confirmed ileocolic intussusception (fig. 2), based on a diffuse large B-cell lymphoma with a diameter of $7 \mathrm{~cm}$ in the wall of the distal ileum. No other localizations of lymphoma were found.

Patient B, a 42-year-old man, visited us because of progressive colicky pains since several months. There was no medical history. The right upper abdomen was tender without palpable lesions or signs of peritonitis. Laboratory results were normal. Ultrasonography was inconclusive. Computed tomography (CT) was performed, revealing ileocecal intussusception (fig. 3). On laparotomy, ileocecal intussusception with impending blow-out of the cecum was found. Resection without previous reduction followed. Recovery was uneventful and the patient was discharged seven days postoperatively. Pathologic evaluation showed that a polypoid lipoma of $3 \mathrm{~cm}$ in diameter was the lead-point for intussusception.

Patient C, a 57-year-old woman, was admitted to the hospital with severe pains in epigastrio, intermittently present for several months. No relevant medical history was present. Palpation was painful without signs of peritonitis. Laboratory results showed microcytic anemia. Ultrasonography revealed the 'target sign' in the right lower quadrant. CT clarified that the intussusception was of the ileo-ileal type. Primary resection of part of the small bowel without previous reduction was performed (fig. 4). Postoperative recovery was uneventful and she was discharged on the 4th postoperative day. Pathologic evaluation and FISH analysis showed that a clear cell sarcoma $2.5 \mathrm{~cm}$ in diameter was the cause.

Patient D, a 78-year-old man, complained of abdominal pains for several months. At age 35, appendectomy had been performed. Stools were normal, no other symptoms were reported. The right lower abdomen was tender with a palpable mass. Laboratory results were normal. Ultrasound revealed a mass without further differentiation. CT showed intussusception of the colon ascendens in the colon transversum without signs of obstruction. Elective right hemicolectomy without reduction was performed with stapled side-side ileo-transversostomy. The patient left the hospital six days postoperatively. Pathology showed stage II adenocarcinoma of the cecum $10 \mathrm{~cm}$ in diameter to be the lead-point.

\section{Discussion}

Symptoms of intussusception can be acute, intermittent or chronic. All patients described had complaints for several months. In two cases ultrasound revealed the 'target sign'. Ultrasonography has been described to be highly sensitive to diagnose intussusception (up to 100\%) [8]. The classic ultrasonographic feature of intussusception is the visualization of two hypo-echoic bowel loops within each other, with an echogenic layer of mesenteric fat in between. On transverse section this produces the characteristic 'target' or 'doughnut sign' [8] (fig. 1). CT signs are virtually pathognomonic. CT is valuable when ultrasonography is inconclusive. Furthermore, CT can better distinguish the exact location of intussusception and may give additional information regarding spread of disease in case of malignancy [9]. Since endoscopy or barium colon 


\begin{tabular}{c|l|l|l}
$\begin{array}{c}\text { CaseReportsin } \\
\text { Gastroenterology }\end{array}$ & $\begin{array}{l}\text { Case Rep Gastroenterol 2007;1:59-64 } \\
\text { D0I: 10.1159/000107473 }\end{array}$ & Published online: August 20, 2007 & $\begin{array}{l}\text { O 2007 S. Karger AG, Basel } \\
\text { ISSN 1662-0631 } \\
\text { www.karger.com/crg }\end{array}$ \\
\hline
\end{tabular}

examinations might cause reduction of the intussusception and manipulation of a possible malignancy, they should not be performed in diagnostic evaluation.

Non-Hodgkin lymphoma was the lead-point in case A. Lymphomas form approximately $25 \%$ of primary small bowel malignancies [7] and have been reported to cause intussusception by several authors, as have lipoma and adenocarcima [1-6]. The clear cell sarcoma of the small bowel found in patient $C$ is a very rare clinical entity with only six reported cases [10]. It has to be distinguished from GIST and (metastatic) melanoma by FISH analysis. The patient described had never had melanoma. We found no earlier report of a clear cell sarcoma causing intussusception.

In adult intussusception, laparotomy is mandatory because malignant lesions are frequently the lead-point. Oncologic resection should be performed. Intraoperative reduction of intussusception should not take place, to prevent possible tumor seeding in case of malignancy and to prevent damaging the bowel $[1-2,4-6]$.

\section{Conclusions}

Treatment of adult intussusception should consist of oncologic resection without previous reduction. Ultrasonography is the first choice in diagnosing intussusception because of its classical appearance and high accuracy.

Fig. 1. Classical target sign with intact intestinal vascularization (patent Doppler flow signals) in patient A.

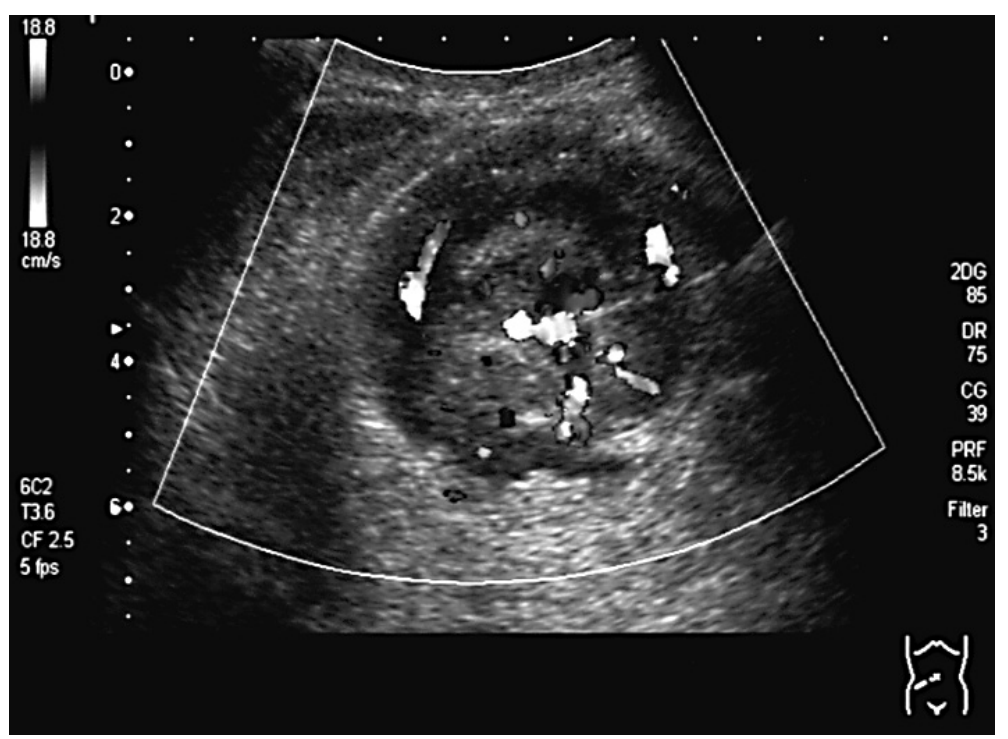


CaseReportsin |Case Rep Gastroenterol 2007;1:59-64 Gastroenterology

Fig. 2. Pathology specimen showing ileocolic intussusception in patient A.

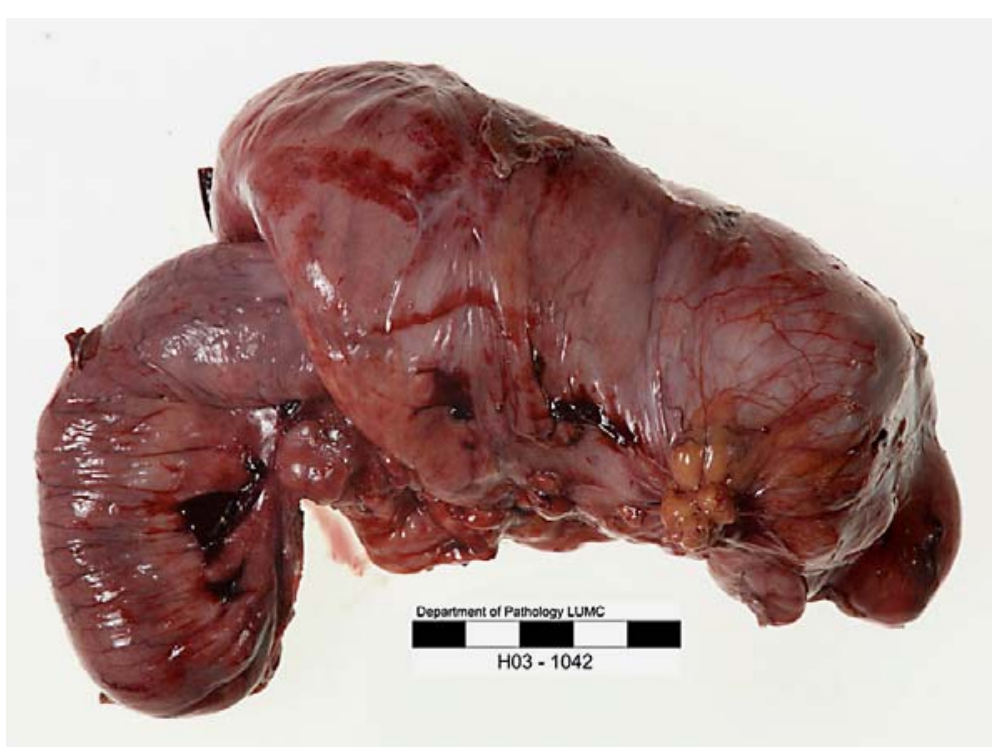




\begin{tabular}{c|l|l|l}
$\begin{array}{c}\text { CaseReportsin } \\
\text { Gastroenterology }\end{array}$ & $\begin{array}{l}\text { Case Rep Gastroenterol 2007;1:59-64 } \\
\text { D0I: 10.1159/000107473 }\end{array}$ & Published online: August 20, 2007 & $\begin{array}{l}\text { @ 2007 S. Karger AG, Basel } \\
\text { ISSN 1662-0631 } \\
\text { www.karger.com/crg }\end{array}$ \\
\hline
\end{tabular}

Fig. 3. CT scan of patient B showing ileocolic intussusception.

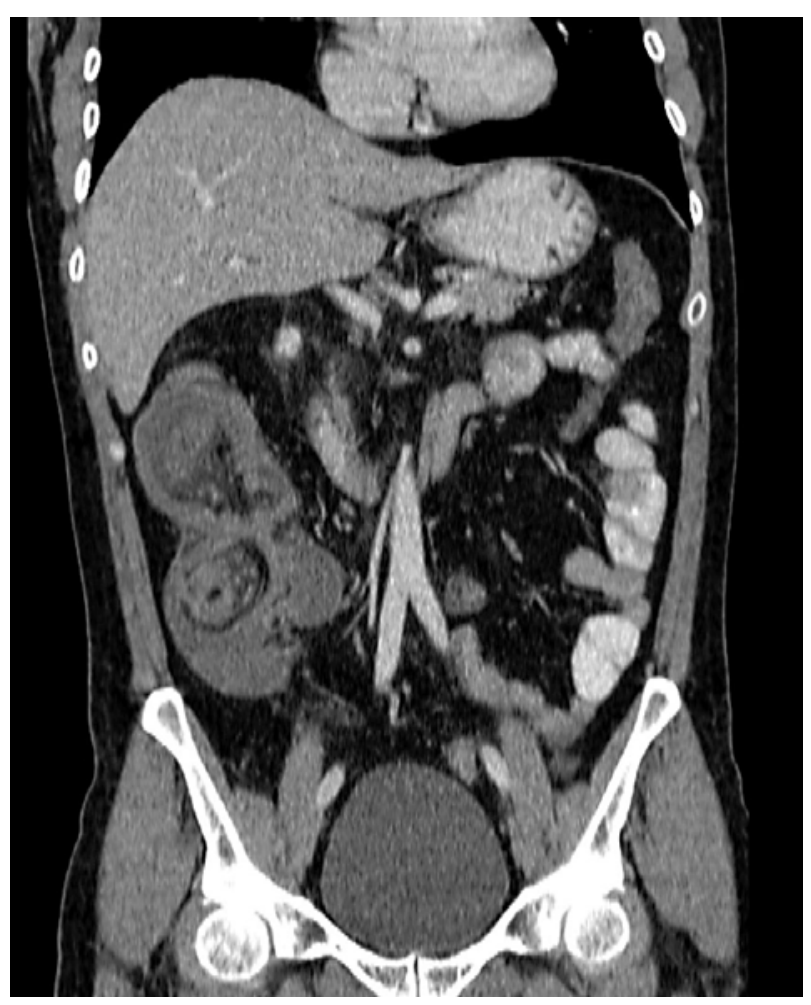

Fig. 4. Patient C. After incision, the removed segment clearly shows the two bowels within each other.

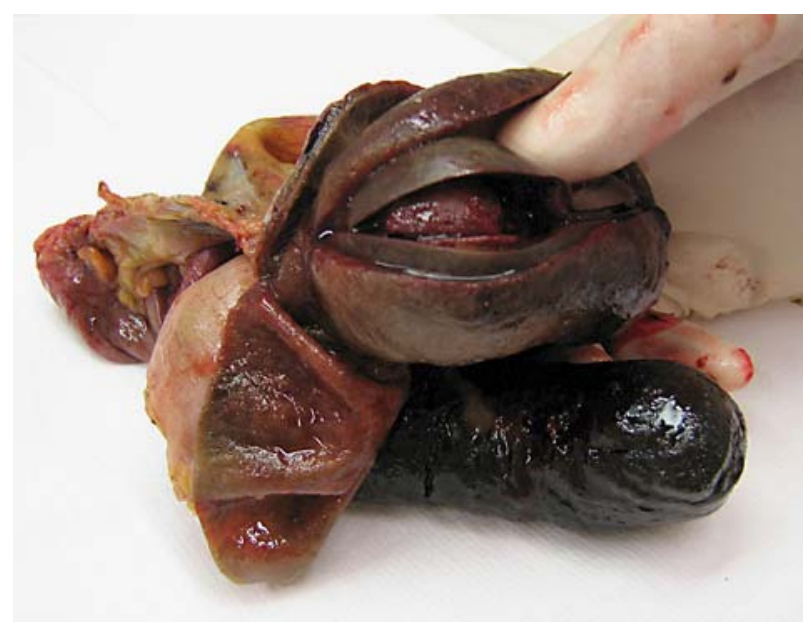




\section{References}

1 Begos DG, Sandor A, Modlin IM: The diagnosis and management of adult intussusception. Am J Surg 1997;173:88-94.

2 Weilbaecher D, Bolin JA, Hearn D, Ogden W 2nd: Intussusception in adults. Review of 160 cases. Am J Surg 1971;121:531-535.

3 Nagorney DM, Sarr MG, McIlrath DC: Surgical management of intussusception in the adult. Ann Surg 1981;193:230-236.

4 Azar T, Berger DL: Adult intussusception. Ann Surg 1997;226:134-138.

5 Eisen LK, Cunningham JD, Aufses AH Jr: Intussusception in adults: institutional review. J Am Coll Surg 1999;188:390-395.

6 Sanders GB, Hagan WH, Kinnaird DW: Adult intussusception and carcinoma of the colon. Ann Surg 1958;147:796-803.

7 Cunningham JD, Aleali R, Aleali M, Brower ST, Aufses AH: Malignant small bowel neoplasms. Histopathologic determinants of recurrence and survival. Ann Surg 1997;225:300-306.

8 Lim JH, Ko YT, Lee DH, Lee HW, Lim JW: Determining the site and causes of colonic obstruction with sonography. Am J Roentgenol 1994;163:1113-1117.

9 Gayer G, Hertz M, Zissin R: CT findings of intussusception in adults. Semin Ultrasound CT MR 2003;24:377-386.

10 Venkataraman G, Quinn AM, Williams J, Hammadeh R: Clear cell sarcoma of the small bowel: a potential pitfall. APMIS 2005;113:716-719. 